\title{
Casestudies over het pedagogische handelen bij een sterfgeval in de klas
}

\author{
Jos van den Brand*
}

\begin{abstract}
Summary
ITE (Initial Teacher Education) cannot prepare students in practice how to respond to bereavement inside their classroom when confronted with this phenomenon. Current case studies can help to solve this problem. In this article, I present the cases of teachers, who had this experience inside their infant class. The case studies are based on four concepts, i.e. narrative identity, contingency, religion, and pedagogical action. Main question of the research is: to what extent is there a relationship between the life stories of teachers in Dutch Catholic primary education and the intentionality of their pedagogical action, when they are confronted with bereavement inside their classroom. At the end of the article some recommendations are given that can be used in ITE.
\end{abstract}

\section{Inleiding}

Dit artikel gaat over het pedagogische handelen van leraren die in hun klas met een sterfgeval werden geconfronteerd. Böhm (2011) stelt dat er twee benaderingen van het pedagogische handelen zijn. De eerste benadering is het technisch-pedagogische handelen. Volgens deze benadering heeft een leraar bij sterfgevallen vooral evidence based kennis nodig waarvan de effectiviteit middels interventies is vastgesteld. De tweede benadering is het praktisch-pedagogische handelen. Deze veronderstelt dat een leraar bij een sterfgeval vooral oordeelkundigheid nodig heeft: het vermogen van leraren om hun handelen af te stemmen op dit kind, met deze achtergrond, in de klas in deze school. Hoewel een leraar beide vormen van het pedagogische handelen nodig heeft, suggereren verschillende auteurs (Böhm 2011; Ricken 1999; IJseling 2020) dat het praktisch-pedagogische handelen de belangrijkste vorm is. Reden hiervoor is dat zich bij een sterfgeval onverwachte situaties voordoen. Een leraar heeft dan geen tijd om te overleggen met collega's

\footnotetext{
* Jos van den Brand is als senior onderzoeker verbonden aan het lectoraat Professionaliseren met Hart en Ziel van de Thomas More Hogeschool in Rotterdam. Daarnaast is hij docent onderzoek en levensbeschouwelijke vorming.
} 
of om protocollen te raadplegen en moet in een fractie van een seconde handelen. Een ervaren leerkracht die ik interviewde verwoordde dit als volgt: "Het kwam compleet onverwacht en ik wist in eerste instantie niet wat ik moest doen."

Van Veen en Janssen (2018) maken aangaande begeleiding bij een sterfgeval onderscheid tussen theoretische kennis en praktijkkennis. Bij theoretische kennis gaat het om de algemene richtlijnen en opvattingen over de begeleiding van rouwende leerlingen die leraren kunnen vinden in boeken, protocollen en op websites. Theoretische kennis is belangrijk, maar onvoldoende om rouwende leerlingen goed te kunnen begeleiden. Die kennis moet ook toegepast en ervaren worden om in specifieke situaties op de leerling toegesneden beslissingen te kunnen nemen. Deze praktijkkennis is vaak impliciet aanwezig en sterk contextgebonden. Het maakt bijvoorbeeld verschil of een leraar werkt in het basisonderwijs of in het voortgezet onderwijs. Bovendien is praktijkkennis sterk persoonsgebonden en wordt mede bepaald door de biografie van leraren. Om deze reden spreken Elbas (2004) en Clandinin (2016) over persoonlijke praktijkkennis. In dit onderzoek richt ik mij daarom op de samenhang tussen het levensverhaal van leraren en de intentionaliteit van hun pedagogische handelen. De centrale vraag luidt: Welke samenhang is er tussen het levensverhaal van leraren en de intentionaliteit van hun pedagogische handelen bij een sterfgeval?

De context speelt een belangrijk rol bij de vorming van praktijkkennis (Van Veen \& Janssen 2018). In dit artikel gaat het om leraren in het Nederlandse katholieke basisonderwijs. Aan deze leraren wordt een specifieke eis gesteld: kinderen leren om te gaan met contingentie-ervaringen en deze te kunnen duiden als een ontmoeting met een andere werkelijkheid (VKLO 2014). Om beginnende leraren voor te bereiden op deze taak is het onvoldoende om hen uitsluitend technische kennis bij te brengen over het pedagogische handelen bij een sterfgeval. Het is ook van belang dat zij zich bezighouden met de duiding van hun eigen contingentie-ervaringen. Mijn veronderstelling is dat ze dan beter in staat zijn om hun leerlingen te ondersteunen bij het omgaan daarmee. Maar de duiding van contingentie-ervaringen is complex, omdat de rol van religie in het leven van mensen sedert de jaren zestig ingrijpend is veranderd (Bernts \& Berghuijs 2015). Enerzijds is er sprake van secularisatie, waarmee ik bedoel dat de deelname aan geïnstitutionaliseerde vormen van religie sterk is afgenomen. Anderzijds zijn er allerlei vormen van ongebonden en persoonlijke religie ontstaan. Het resultaat van deze twee trends is dat de rol van religie in het leven van leraren fluide is geworden. Leraren verlaten de religie waarin ze zijn gesocialiseerd of kiezen voor een andere vorm van 
religie, al dan niet geïnstitutionaliseerd. Om recht te doen aan deze pluraliteit ga ik ervan uit dat mensen hun persoonlijke identiteit scheppen door een levensverhaal te reconstrueren (Van den Brand 2016). Ik onderzoek hoe leraren in deze verhalen betekenis geven aan contingentie-ervaringen. Bovendien kan ik dan ook nagaan welke samenhang er is tussen het levensverhaal van leraren en de intentionaliteit van hun pedagogische handelen.

\section{Theoretische uitgangspunten}

\section{Narratieve identiteit}

De narratieve benadering van identiteit veronderstelt dat mensen hun identiteit uitdrukken in een levensverhaal dat voortdurend wordt gereconstrueerd om samenhang, richting en betekenis aan hun leven te geven (Van den Brand 2016). Ik volg Straub (2019b) die in zijn theorie over de narratieve identiteit van personen een relatie met contingentie legt. Hij stelt dat contingentieervaringen de samenhang van een levensverhaal verstoren. Ze bieden aan een persoon nieuwe handelingsmogelijkheden of tasten de bestaande aan. Om de samenhang van het levensverhaal te behouden, worden de contingentieervaringen narratief bewerkt. Straub bedoelt dat een contingentie-ervaring een begin, een midden, een einde en een plot krijgt. Daardoor wordt het mogelijk om de contingentie-ervaring op te nemen in het levensverhaal. Zo kunnen mensen zich openstellen voor veranderingen, zonder dat ze hun identiteit compleet hoeven te veranderen.

De plot van het verhaal wordt gevormd door de nagestreefde levensdoelen (Van den Brand 2016). Deze levensdoelen representeren de uiteindelijke waarden in ons leven. De zingeving aan levensgebeurtenissen komt tot stand door ons af te vragen wat ze voor de realisering van onze levensdoelen betekenen. Gebeurtenissen die bijdragen aan de realisering van onze levensdoelen waarderen we als een hoogtepunt. Omgekeerd waarderen we gebeurtenissen die een belemmering zijn voor de realisering van onze levensdoelen als een dieptepunt. Verder bepaalt de zingeving aan levensgebeurtenissen mede de intentionaliteit van ons handelen. Een voorbeeld is een vrouw met het levensdoel 'zorgen voor anderen'. Ze waardeert de geboorte van haar dochter als een hoogtepunt en is bereid om langdurig voor haar te zorgen. Om samenhang en richting aan onze handelingen te geven, vertalen we onze levensdoelen ook naar andere levensgebieden zoals het beroepsleven (Ricoeur 2005). Anders gezegd, er is een samenhang tussen de levensdoelen en de intentionaliteit van het pedagogische handelen. De eerdergenoemde vrouw kiest bijvoorbeeld 
voor een baan op een basisschool in een achterstandswijk omdat het past bij haar levensdoel.

\section{Contingentie}

Contingentie is een filosofisch begrip dat aangeeft dat fenomenen in de werkelijkheid er ook niet of anders kunnen zijn. In dit onderzoek richt ik mij op wat Zirfas (2010) noemt absolute contingentie. Daarbij gaat het om fenomenen die er ook niet of anders kunnen zijn, maar niet door ons veranderd kunnen worden. We kunnen niet veranderen dat we er zijn zoals we er zijn (nataliteit) en dat we eindig zijn (mortaliteit). Bovendien krijgen we te maken met onverwachte gebeurtenissen die ons kunnen maken of breken en om een interpretatie vragen. Verder kunnen we absolute contingentie onderverdelen in gelukkige contingentie en tragische contingentie. Er is sprake van gelukkige contingentie, als gebeurtenissen die niet fundamenteel door mensen zijn veroorzaakt, zich uiteindelijk zo voegen, dat ze aan de verwachtingen en wensen van mensen voldoen. Denk bijvoorbeeld aan de onverwachte ontmoeting met de levenspartner. Bij tragische contingentie kunnen mensen niet voorkomen of verhinderen dat ze worden getroffen door een gebeurtenis die voor hen nadelige gevolgen heeft. Een voorbeeld is: aan een erfelijke ziekte lijden.

Wuchterl (2011) wijst erop dat mensen op verschillende manieren met absolute contingentie kunnen omgaan. De eerste manier is contingentie ontkennen. In dat geval gaan mensen ervan uit dat alle fenomenen in de werkelijkheid noodzakelijk zijn. Een persoon krijgt bijvoorbeeld te horen dat hij lijdt aan een ongeneeslijke vorm van kanker. Hij gaat ervan uit dat de lichamelijke pijn en de psychische stress volledig zijn te verklaren door noodzakelijke biologische processen. De tweede manier is contingentie erkennen. Mensen beseffen dat er grenzen zijn aan de mogelijkheden van hun denken en handelen. Iemand weet bijvoorbeeld dat hij de ziekte ALS niet zal overleven. Hij vraagt zich af waarom hem deze ziekte moest overkomen. De derde manier is contingentie ontmoeten. In dat geval wordt de grens van ons denken en handelen niet alleen erkend, maar ook gezien als een ontmoeting met een andere werkelijkheid voorbij deze grens. Iemand gelooft bijvoorbeeld dat er leven na de dood is.

\section{Religie}

Riesebrodt (2010) stelt dat het concept contingentie ons verder kan helpen om de rol van religie in het levensverhaal van mensen te onderzoeken. Hij omschrijft religie als een zoekproces naar heil en bemiddeling van heil. Dit 
zoekproces komt volgens Riesebrodt op gang als mensen te maken krijgen met situaties die hen te boven gaan, maar bij het mens-zijn horen. Het gaat dan om contingentie-ervaringen zoals sterfelijkheid, gebrek aan controle over de natuurlijke omgeving en instabiliteit in sociale relaties. Religie helpt mensen betekenis te geven aan deze situaties door ze met bovenmenselijke machten in verband te brengen. Mensen kunnen daardoor betekenis geven aan gebeurtenissen waarbij ze tegen hun eigen grenzen aanlopen, maar wel in staat blijven om te handelen. Volgens Joas (2012) heeft het begrip contingentie te maken met het beseffen en ervaren van beslissings- en handelingsruimte. Als mensen gebruik maken van deze handelingsruimte leidt dat tot pluralisering. Op het gebied van religie komt dit bijvoorbeeld tot uitdrukking in de constructie van een 'patchworkidentiteit'. Joas (2004) bedoelt daarmee dat mensen elementen uit verschillende religieuze tradities op hoogstpersoonlijke wijze combineren. De toegenomen handelingsopties kunnen als een verlossende bevrijding worden ervaren, maar ook als een belastende dwang om voortdurend keuzes te moeten maken. Verder merkt Joas (2012) op dat religie vaak in verband wordt gebracht met de tragische vormen van contingentie. Joas vindt het eenzijdig om religie alleen met deze vormen van contingentie in verband te brengen. Het is ook van belang om religie in verband te brengen met begeestering en met gevoelens van dankbaarheid en genade.

\section{Het pedagogische handelen}

Het vierde kenbegrip is: het pedagogische handelen. Zoals al opgemerkt kunnen we volgens Böhm (2011) twee benaderingen van het pedagogische handelen onderscheiden. De eerste benadering is: het technisch-pedagogische handelen (TPH). De leraar heeft vooral (technische) kennis nodig omtrent technieken en gereedschappen waarvan de effectiviteit middels interventiestudies is vastgesteld. Om grip te krijgen op de contingentie-ervaring van de dood is er de afgelopen decennia door psychologen veel onderzoek gedaan naar de rouwbegeleiding van kinderen (Alisic 2011; Spuij 2014). Dat onderzoek is gericht op hoe kinderen het beste begeleid kunnen worden als ze een dierbare verliezen. Er zijn materialen en rouwprotocollen ontwikkeld die leraren kunnen gebruiken bij het omgaan met een sterfgeval. De tweede benadering is: het praktisch-pedagogische handelen (PPH). In dat geval wordt begeleiding als praktisch handelen verstaan en heeft de leraar oordeelkundigheid nodig. In de onderwijscontext is het de persoonlijke praktijkkennis waarmee je in een onverwachte situatie, in een split second beoordeelt wat pedagogisch gezien wenselijk is. Böhm, Scheifelbein en Seichter (2017) wijzen erop dat deze benadering het contingente karakter van opvoeden en onderwijzen 
erkent, omdat er niet vanuit wordt gegaan dat situaties vooraf volledig verklaar- en planbaar zijn, en met risico en onzekerheid gepaard gaan. Het is zelfs mogelijk dat het pedagogische handelen mislukt. In de praktijk heeft een leraar allebei nodig. Hij moet enerzijds technische kennis hebben van de beschikbare gereedschappen en technieken en deze kunnen hanteren, en anderzijds het vermogen hebben om in een onverwachte, unieke situatie - als deze leraar in relatie tot dit kind - te beoordelen of die gereedschappen hier passen of niet.

\section{Methode}

\section{Onderzoeksvragen en onderzoeksdesign}

De centrale vraag gaat over de samenhang tussen het levensverhaal van leraren enerzijds en de intentionaliteit van hun pedagogische handelen anderzijds. Om deze samenhang te onderzoeken formuleerde ik drie deelvragen.

1 Welke duiding geven leraren in het Nederlandse katholieke basisonderwijs aan hun contingentie-ervaringen? Volgens de narratieve benadering van identiteit interpreteren personen contingentie-ervaringen als een hoogteof een dieptepunt op grond van hun levensdoelen. Om de rol van religie te achterhalen, ga ik na of deze hoogte- en dieptepunten worden geduid als een ontmoeting met een andere werkelijkheid.

2 Welke vorm van pedagogisch handelen gebruiken leraren in het Nederlandse katholieke basisonderwijs bij een sterfgeval in hun klas? Door de beantwoording van deze deelvraag onderzoek ik of leraren gebruik maken van het TPH of het PPH bij een sterfgeval in hun klas.

3 In hoeverre zijn de levensdoelen die leraren nastreven en de duiding van hun contingentie-ervaringen verbonden met de intentionaliteit van hun pedagogische handelen? Ik ga na of de veronderstelling juist is dat de levensdoelen van leraren en hun zingeving aan contingentie-ervaringen samenhangen met de intentionaliteit van hun pedagogische handelen, zoals de narratieve benadering van identiteit veronderstelt.

Ik kies voor een casestudy om ruimte te maken voor diepgang en arbeidsintensieve werkwijzen (Verschuren \& Doorwaard 2015). Het gaat om zaken die liggen opgeslagen in de psyche van de leraar. Deze zaken zijn niet gemakkelijk toegankelijk, omdat leraren zich hiervan niet direct bewust zijn. Dit is bijvoorbeeld het geval bij de praktijkkennis die impliciet een rol speelt bij 
het pedagogische handelen en nog niet eerder is verwoord. Verder kies ik voor een casestudie vanwege een kwalificerende en interpreterende benadering (Verschuren \& Doorewaard 2015). Ik wil graag begrijpen hoe leraren handelen bij een sterfgeval en wat de rol daarbij is van hun biografie. Tenslotte kies ik voor een casestudie omdat het mogelijk is om empirisch onderzoek te doen. Daarbij gebruik ik het semigestructureerd interview om inzicht te krijgen in de belevingswereld van leraren en de betekenis die ze geven aan hun ervaringen (Bleijenbergh 2016). Bovendien wijst Simons (2009) erop dat de casestudie zeer geschikt is voor onderwijsonderzoek, omdat zo inzicht wordt verkregen in hoe leraren onder concrete omstandigheden beslissingen nemen. Daarbij is het doel van de onderzoeker niet representativiteit, maar het unieke en het bijzondere van een casus in kaart brengen.

Volgens Abma en Stake (2014) heeft een natuurlijke casestudie vijf kenmerken. Het gaat om een casus in zijn oorspronkelijke context en niet om een situatie die door de onderzoeker is gecreëerd. De genoemde kenmerken verduidelijk ik door voorbeelden te geven. Het eerste kenmerk is: aandacht voor unieke en onverwachte kwesties. Hoewel in een casestudie vanuit theoretische veronderstellingen en een vraagstelling wordt vertrokken, blijft er ruimte voor kwesties, vragen en aandachtspunten die opkomen vanuit een casus. De onderzoeker kan vooraf niet inschatten wat de complexiteit en de uniciteit van een casus inhouden en welke onverwachte zaken een rol spelen. Bij de casus van Cox (zie hierna) is bijvoorbeeld het unieke en onverwachte dat de moeder niet weet hoe ze aan haar dochter moet vertellen dat haar vader is overleden. Het tweede kenmerk is: rekening houden met de invloed van de context. Het menselijke handelen kan niet los van zijn context worden begrepen. Bij de context in smallere zin gaat het om deze leraar, met deze kinderen, met deze achtergrond, in deze school. Bij de context in ruimere zin gaat het om de culturele, historische, sociaaleconomische en politieke context. De casestudies spelen zich bijvoorbeeld af op Nederlandse katholieke basisscholen. Het derde kenmerk is: betekenis en interpretatie. Het gaat bij een casestudie om begrijpen in tegenstelling tot verklaren. Uitgangspunt is het idee dat mensen in de wereld zijn en daaraan betekenis geven in interactie met anderen. De onderzoeker probeert te begrijpen welke interpretatie mensen aan hun ervaringen geven. Ik probeer bijvoorbeeld te begrijpen welke betekenis leraren aan hun autobiografische contingentie-ervaringen geven. Het vierde kenmerk is: een holistische benadering. Hiermee wordt bedoeld dat de onderzoeker probeert om een zo compleet mogelijk beeld te krijgen van de casus. Dit gebeurt door te observeren, te interviewen, documentanalyse en door de casus te interpreteren. In dit onderzoek beperkte ik me tot het inter- 
viewen van leraren en ging na of ze een rouwprotocol gebruikte. Het vijfde kenmerk is: leren van een casus. Het gaat bij de selectie van een casus niet om representativiteit, maar om de vraag wat we kunnen leren van een unieke casus. Dit wordt ook wel het leerpotentieel van een casus genoemd. Ik geef verderop aan hoe casusbeschrijvingen in de initiële lerarenopleiding gebruikt kunnen worden.

\section{Het semigestructureerde interview en de werving van respondenten}

Om de onderzoeksvragen te beantwoorden, zijn leraren geïnterviewd met een semigestructureerd interview dat ik ontwikkelde (Van den Brand 2016). In het eerste deel van interview tekent de respondent een levenslijn en geeft daarbij hoogte- en dieptepunten in het verleden, het heden en de toekomst aan. Vervolgens vertelt de respondent wat deze gebeurtenissen voor haar of hem tot een hoogte- of dieptepunt maakten op het moment dat ze plaatsvonden of zullen plaatsvinden. In het tweede deel van het interview is nagegaan welke betekenis respondenten geven aan onverwachte hoogte- en dieptepunten vanuit het perspectief van contingentie. Met een meetinstrument dat Scherer-Rath (2013) ontwikkelde, is achterhaald of respondenten contingentie-ervaringen ontkennen, erkennen of duiden als een ontmoeting met een andere werkelijkheid. In het derde deel van het interview is onderzocht welke levensdoelen een respondent nastreeft. Het vierde deel van het interview is ontwikkeld voor dit onderzoek. Aan de respondenten is gevraagd om eerst vanuit hun eigen perspectief te vertellen over belangrijke gebeurtenissen tijdens het sterfgeval in hun klas. Daarna is nagegaan wie het initiatief nam in deze situaties, hoe daarop is gereageerd door de betrokken personen en in hoeverre het ertoe deed dat de leraar er was en niet iemand anders.

De respondenten zijn geworven door aan schoolopleiders, met wie de onderzoeker samenwerkt, te vragen of ze hem in contact konden brengen met leerkrachten die de afgelopen twee jaar met een sterfgeval in hun klas werden geconfronteerd. Van de tien benaderde respondenten waren er uiteindelijk zeven bereid om mee te werken aan een interview. Een respondent vond het emotioneel te belastend om mee te werken aan een interview en twee andere respondenten trokken zich terug uit tijdgebrek.

\section{Analysedesign}

De interviews zijn opgenomen en woord voor woord uitgeschreven. De getranscribeerde interviews zijn geanalyseerd met Atlas.ti 8 volgens de constant vergelijkende methode (Friese 2019). Kortgezegd wil dit zeggen dat er is gewerkt met open codes, axiale codes en selectieve codes. ${ }^{1}$ Om de 
betrouwbaarheid te vergroten codeerden onderzoekers van het lectoraat professionaliseren met Hart en Ziel van de Thomas More Hogeschool in Rotterdam dezelfde teksten. De resultaten werden besproken, tot er overeenstemming was over het toekennen van de codes (Bleijbergh 2016).

\section{Resultaten}

\section{De duiding van autobiografische contingentie-ervaringen}

In deze paragraaf beantwoord ik de vraag: welke duiding geven leraren in het Nederlandse katholieke basisonderwijs aan hun contingentie-ervaringen? Het gaat om onverwachte levensgebeurtenissen die leraren zijn overkomen en ik ga na of deze zijn geduid als contingentie-ontkenning, contingentie-erkenning of contingentie-ontmoeting.

\section{Gelukzalige contingentie-ervaringen}

De eerste vorm van gelukzalige contingentie is: het onverwachte begin van relaties. Het gaat om de ontmoeting met de huidige levenspartner en de geboorte van een kind. Deze gebeurtenissen worden door de respondenten geduid als contingentie-erkenning. Bos zegt over het ontstaan van de relatie met haar levenspartner: "Ik was sowieso niet op zoek naar iemand... eerst een hele tijd vrienden geweest... onverwacht dat ik dan (ten huwelijk JvdB) gevraagd werd." Dat het om contingentie-erkenning gaat, blijkt uit de woorden "was niet op zoek naar iemand", "onverwacht" en "gevraagd werd". Faber is onverwacht zwanger geworden. Ze zegt: "Ik dacht dat het niet mogelijk was, toen kreeg ik toch een kindje. Het had ook anders kunnen lopen, daar ben ik dankbaar voor." Uit de woorden "ik dacht dat het niet mogelijk was" en "het had ook anders kunnen lopen" leid ik af dat het om contingentie-erkenning gaat.

De tweede vorm van gelukzalige contingentie is: onverwacht succes in relaties. De ouders van Derks scheidden toen ze nog jong was. De verstandhouding tussen haar ouders bleef goed en daardoor had ze toch een gelukkige jeugd. Ze zegt: "Ik heb echt geluk gehad dat mijn ouders heel goed met elkaar bleven omgaan." Uit de woorden "Ik heb echt geluk gehad" blijkt dat het ook anders had kunnen zijn en dat Derks contingentie erkent.

De derde vorm van gelukzalige contingentie is: onverwacht succes in ontwikkeling. Evers is gezakt voor haar mavo-examen en blijft zitten. In het jaar dat ze doubleert komt ze tot het inzicht dat ze geen kapster wil worden, maar leerkracht. In haar woorden: “Omdat ik gezakt was, kwam ik erachter dat de 
kappersopleiding geen goede keuze was.” Verder zegt Evers: “Ik zeg altijd: 'het had zo moeten zijn." Uit de woorden "het had zo moeten zijn”, maak ik op dat het in haar ogen niet anders had kunnen zijn. Dit betekent dat ze contingentie ontkent.

De vierde vorm van gelukzalige contingentie is: onverwacht succes in gezondheid. Tijdens de zwangerschap van haar eerste kind kreeg Bos te maken met een levensbedreigende ziekte: een acute longembolie. Ze overleefde de ziekte en baarde een gezond kind. Ze duidt deze contingentie-ervaring als een ontmoeting met andere werkelijkheid, omdat ze met de eindigheid van haar eigen bestaan en van haar ongeboren kind geconfronteerd werd. Ze zegt: “Bij de longembolie werd ik met mijn neus op de feiten gedrukt... Ik stond erbij stil hoe kort het leven is. Er waren momenten dat ik God wilde bedanken." Het feit dat Bos dankbaar jegens God is, duidt op contingentie-ontmoeting.

\section{Tragische contingentie-ervaringen}

De eerste vorm van tragische contingentie is: onverwacht falen in relaties. Cox is belast met een erfelijke aanleg voor kanker. Ze moet aan haar kinderen vertellen dat ook zij met dit gen belast kunnen zijn. Ze zegt: "Het vertellen aan mijn kinderen was een dieptepunt. Ze hebben ook vijftig procent kans op het gen." Na het vertellen krijgt haar dochter psychische problemen. In haar woorden: "Mijn dochter kreeg opeens faalangst, die was ook weer vijftien jaar (de leeftijd waarop Cox haar vader verloor JvdB)...Het waren lastige dingen... ik wilde niet dat ze daar last van had." Cox erkent contingentie, omdat ze niet kan voorkomen of verhinderen dat haar dochter belast is met een erfelijk gen en daardoor psychische problemen krijgt.

De tweede vorm van tragische contingentie is: onverwacht einde van relaties. Bij het einde van relaties speelt de contingentie-ervaring van de dood op twee manieren een rol in de levensverhalen van leraren. Op de eerste plaats verliezen leraren dierbaren. Cox verliest bijvoorbeeld op jonge leeftijd haar vader, omdat hij aan kanker overlijdt. Ze moet waken bij haar vader en voor haar jongere broertjes zorgen. Ze zegt: "Ik ging drie maanden niet naar school, omdat ik overdag waakte (bij mijn vader JvdB) en mijn moeder 's nachts. Het was heel beladen en ik voelde me ook eenzaam." Na het overlijden van haar vader draagt ze de verantwoordelijkheid voor haar jongere broertjes, omdat haar moeder suïcidaal is. In haar woorden: "Ik kreeg veel verantwoording. Toen mijn vader was overleden, zag mijn moeder het niet meer zitten en wilde zelfmoord plegen. Ik was zo bang en zorgde voor mijn broertjes." Over de duiding van deze gebeurtenis vertelt Cox: "Het is mij overkomen...het heeft mij een stuk jeugd ontnomen...ook mijn moeder wist niet hoe ze het moest doen... 
dan loopt het zo." Uit de woorden “overkomen”, “ontnomen” en "dan loopt het zo" leid ik af dat ze contingentie erkent. Op de tweede plaats worden leraren geconfronteerd met hun eigen sterfelijkheid. De meeste respondenten duiden hun eigen dood als een ontmoeting met een andere werkelijkheid. Ze gaan ervan uit dat ze na hun overlijden ergens voortleven. Bos zegt bijvoorbeeld over haar eigen voortleven na de dood: "Ik hoop dat ik naar de hemel ga... dat ik herenigd wordt met degenen die ik heb verloren." Dat het bij Bos om contingentie-ontmoeting gaat, leid ik af uit de woorden "naar de hemel ga". Weer een ander voorbeeld is Aarts. Hij neemt over de duiding van zijn eigen dood een ambivalent standpunt in. Enerzijds zegt hij niet te weten of er leven na de dood is: "Is er iets? Ik weet het niet. Het zou kunnen." Anderzijds gelooft hij dat zijn ziel ergens voortleeft: "Als ik dood ben, denk ik toch dat ik ergens nog een ziel heb." Ook brengt hij het voortleven na de dood in verband met de hemel. Hij zegt: "Ik hoop...dat ik goed heb geleefd voor als de hemel toch wel bestaat." Hier klinkt de ook door christenen wel aangehangen gedachte in door dat je gedrag tijdens je leven bepaalt wat er na de dood met je gebeurt. Verder gebruikt hij het begrip karma. Karma wordt gebruikt in oosterse religies en is nauw verbonden met de reïncarnatiegedachte. Je keert na je dood terug in een andere gedaante en dit hangt af van hoe je je gedroeg. Aarts gaat ervan uit dat als hij nu goed leeft, dat hij daar op een later tijdstip voordeel van heeft: "Ik geloof eerder in karma...als ik iets goeds doe, dan gebeurt er ook iets goeds met mij." Ik stel vast dat Aarts op hoogstpersoonlijke wijze elementen uit verschillende religies combineert. We zagen dat Joas (2004) in dat geval spreekt over een 'patchworkidentiteit' op het gebied van religie.

De derde vorm van tragische contingentie is: onverwacht falen in ontwikkeling. Evers zakte onverwacht voor haar mavo-diploma en kon niet meer herkansen. Ze zegt: "Ik was er niet vanuit gegaan (dat ik zou zakken JvdB)...en niet meer kon herkansen." Uit de woorden "ik was er niet vanuit gegaan" maak ik op dat het om contingentie-erkenning gaat.

De vierde vorm van tragische contingentie is: onverwacht falen in gezondheid. Aarts was 15 jaar toen hij twee maanden niet naar school ging, omdat hij ziek was. Aarts zegt: "De artsen konden niks vinden... Ik was bij een psycholoog en hij wist ook niet wat het was." Hij erkent contingentie, omdat er geen verklaring voor zijn ziekte is. Dit leid ik af uit de woorden "niks vinden" en "wist ook niet wat het was". Cox krijgt op tweeënveertigjarige leeftijd, de leeftijd waarop haar vader overleed, te horen dat in haar vaders familie de aanleg voor kanker erfelijk is. Ze staat voor de keuze om te laten uitzoeken of ze erfelijk belast is. Ze zegt: "Ik was er gelijk bang voor. Ik was bij wijze van spreken mijn begrafenis al aan het regelen." Er is sprake van contingentie- 
ontmoeting, omdat ze een Hogere Macht om hulp vraagt tijdens de onderzoeken in het ziekenhuis. Ze zegt: “Toen ik naar het ziekenhuis reed, deed ik gebedjes: 'Laat het alsjeblieft goed gaan.” Ze is ambivalent over haar verhouding tot een Hogere Macht. Ze bidt alleen als het slecht met haar gaat: "Het is eigenlijk heel oneerlijk. Als het slecht gaat, dan ga ik wel bidden. Daarom weet ik ook niet of ik geloof. Het zijn dingen die ik uitsprak, omdat ik het zo graag anders zou willen. Maar spreek ik tot God of een Hogere Macht, ik weet het niet." In de woorden "als het slecht gaat, dan ga ik wel bidden" en "die ik uitsprak, omdat ik het zo graag anders zou willen" klinkt het theïstische godsbeeld door van een bovennatuurlijk wezen dat zich persoonlijk met het leven van afzonderlijke mensen bezighoudt. Tegelijkertijd past de twijfel over het theïstische godsbeeld in de tendens dat steeds minder mensen in de laatmoderne samenleving geloven in dit godsbeeld (Smedes 2016).

\section{Conclusie}

Ik constateer dat gelukzalige en tragische contingentie-ervaringen een rol spelen in de levensverhalen van de leraren die meewerkten aan het onderzoek. In de meeste gevallen erkennen ze contingentie. Verder heb ik aanwijzingen dat contingentie-ontmoeting een rol speelt bij de confrontatie met een levensbedreigende ziekte en bij de eigen sterfelijkheid. Dit sluit aan bij de religietheorie van Riesebrodt (2010) die ervan uitgaat dat mensen naar bemiddeling van heil zoeken als ze met hun eigen sterfelijkheid worden geconfronteerd.

\section{Het pedagogische handelen bij een sterfgeval}

In deze paragraaf beantwoord ik de vraag: welke vorm van pedagogisch handelen gebruiken leraren in het Nederlandse katholieke basisonderwijs bij een sterfgeval in hun klas? We hebben gezien dat er twee vormen van het pedagogische handelen zijn: het technisch-pedagogische handelen (TPH) en het praktisch-pedagogische handelen $(\mathrm{PPH})$. Ik veronderstel dat er sprake is van TPH als leraren gebruik maken van rouwverwerkingsmateriaal, een rouwprotocol, tips ontvangen van een maatschappelijk werker en in boeken en op websites technische kennis opzoeken. Er is sprake van PPH als leerkrachten hun pedagogische handelen afstemmen op dit kind, in deze situatie, in deze klas, in deze school.

\section{Exclusief praktisch handelen}

Er zijn twee leraren die zeggen dat ze uitsluitend gebruik maken van het PPH. In de klas van Faber overleed een leerling aan kanker. Ze handelde naar eigen goeddunken en in nauw overleg met de ouders. Faber zegt: “We hebben het 
echt zelf ingevuld...en in overleg met de ouders." De woorden "het echt zelf ingevuld" geven aan dat er uitsluitend sprake is van PPH. Geurts zegt over zijn pedagogische handelen dat hij de leerling de ruimte gaf om erover te vertellen: "Ik had afgesproken...als hij wilde dan zou hij erover vertellen. En dat is ook gebeurd, hij heeft er heel veel over verteld. Ik vond heel belangrijk dat ook de kinderen van de klas zouden weten, wat hij meemaakte.” Er is sprake van PPH omdat hij niet naar technische kennis verwijst.

\section{Combinatie van het technische en het praktische handelen}

Vijf leraren combineren het TPH en het PPH. Ik geef twee voorbeelden ter verduidelijking. Cox zegt over haar pedagogische handelen bij een sterfgeval: "Ik liet mij leiden door mijn gevoel en de dingen die ik erover las. Ik googelde nog, maar deed vooral wat mijn hart mij ingaf." Uit de woorden "ik liet mij leiden door mijn gevoel" en "deed vooral wat mijn hart mij ingaf" maak ik op dat Cox het pedagogische handelen interpreteert als PPH. Verder blijkt uit de woorden "de dingen die ik erover las" en "ik googelde nog" dat er ook sprake was van TPH. Tot slot licht uit de woorden "deed vooral wat mijn hart mij ingaf" op, dat het accent lag op het PPH. Derks wist dat een moeder van een leerling uit haar klas zou overlijden. Ze nam vooraf met de directeur van de school en haar duocollega het rouwprotocol door. Ook gebruikte ze verhalen en materialen uit de verdrietkoffer. Toch is het PPH in haar ogen het belangrijkste. Ze zegt: “Uiteindelijk moest ik ...op mijn gevoel afgaan.” Dat het om PPH gaat, maak ik op uit de woorden "moest ik...op mijn gevoel afgaan.”

Ik kom tot de conclusie dat voor alle leraren geldt dat in hun ogen het PPH het belangrijkste is. Verder springt in het oog dat de oordeelkundigheid niet zozeer een rationele afweging is, als wel het intuitief aanvoelen van wat er nodig is in een situatie. Van Manen (2014) spreekt in dit verband over pedagogische tact. Het is een soort impliciete of stilzwijgende kennis, die een leraar opdoet in de praktijk en hem/haar in staat stelt zijn/haar handelen af te stemmen op de concrete situatie waarin hij/zij zich bevindt.

\section{Samenhang levensdoelen, duiding contingentie-ervaringen en het pedagogische handelen bij een sterfgeval}

In deze paragraaf beantwoord ik de vraag: in hoeverre is er samenhang tussen de levensdoelen die leraren nastreven en de duiding van hun contingentieervaringen verbonden met de intentionaliteit van hun pedagogische handelen bij een sterfgeval in hun klas?

Om te beginnen zijn er leraren die een verband leggen tussen de nagestreefde levensdoelen en hun PPH. Derks streeft het zelfgerichte levensdoel 
'gelukkig worden' en het andergerichte levensdoel 'verbondenheid met anderen' na. Haar tweede levensdoel speelde een rol bij haar PPH bij het sterfgeval. Derks zegt dat ze het belangrijk vindt om kinderen te leren "omgaan met tegenslag." Ze bedoelt daarmee dat: "Je elkaar helpt en er voor elkaar bent... Deze gebeurtenis was eigenlijk het perfecte voorbeeld.” Evers streeft de zelfgerichte levensdoelen 'gelukkig worden' en 'zelfontwikkeling' na. Ze zegt dat met name het laatstgenoemde levensdoel van belang is voor haar PPH bij een sterfgeval. Ze zegt: "dat ik aan de kinderen in de klas..meegeef dat er ook tegenslagen zijn." Ik merk op dat de gerichtheid van de nagestreefde levensdoelen ervoor zorgt dat de leraren andere accenten leggen in hun PPH. Derks benadrukt de interpersoonlijke vorming wat past bij de andergerichtheid van haar levendoel, namelijk elkaar helpen. Terwijl Evers zich meer op de intrapersoonlijke vorming richt, te weten leren omgaan met tegenslagen in het leven. Dit is in lijn met de zelfgerichtheid van haar levensdoel.

Verder zijn er leraren die verband leggen tussen de duiding van hun contingentie-ervaringen en het praktisch-pedagogische handelen. Cox verwijst bijvoorbeeld naar de tragische contingentie-ervaring uit haar jeugd. "Ik ben mijn leven op een bepaalde manier gestart en dat is niet altijd leuk geweest." Over de wijze waarop deze contingentie-ervaring doorwerkt in haar PPH zegt Cox: "Daardoor ben ik heel erg bezig met dat de kinderen gelukkig worden... Geniet maar van wat je doet en zorg voor elkaar." Ook bij het vertellen van het slechte nieuws aan de leerling speelt de contingentie-ervaring uit haar jeugd een rol: "Ik wilde dat heel graag zo goed mogelijk doen, en dan speelt...mijn achtergrond mee, mijn vader is ook jong overleden."

Ik kom tot de voorzichtige conclusie dat levensdoelen een rol lijken te spelen bij de accenten die leraren leggen bij het PPH bij een sterfgeval. Daarnaast heb ik aanwijzingen dat de duiding van contingentie-ervaringen doorklinkt in het PPH. Bovendien heb ik de indruk dat het PPH gericht is op 'leren leven' (Göhlich \& Zirfas 2007). Leraren vinden het belangrijk dat kinderen leren omgaan met tragische contingentie-ervaringen door elkaar te helpen of te accepteren dat deze bij het leven horen. Hoewel leraren hun leerlingen leren om contingentie te erkennen, lijkt contingentie-ontmoeting geen rol te spelen. Terwijl dit wel wordt verwacht van leraren in het katholieke basisonderwijs.

\section{Beantwoording centrale vraag}

De centrale vraag luidt: Welke samenhang is er tussen het levensverhaal van leraren en de intentionaliteit van hun pedagogische handelen bij een sterfgeval? Om deze vraag te beantwoorden onderzocht ik eerst welke duiding leraren gaven aan hun eigen contingentie-ervaringen. Meestal erkennen leraren 
contingentie. De confrontatie met hun eigen eindigheid wordt geduid als contingentie-ontmoeting. Vervolgens ging ik na welke vorm van pedagogisch handelen leraren gebruikten bij een sterfgeval. Hoewel de meeste leraren het TPH en het PPH combineerden, was de laatstgenoemde vorm het belangrijkste. Het ging om het intuïtief aanvoelen wat een situatie vraagt van een leraar. Tot slot onderzocht ik de samenhang tussen levensdoelen en de duiding van contingentie-ervaring enerzijds en intentionaliteit van het praktisch-pedagogische handelen anderzijds. Het lijkt erop dat levensdoelen en de duiding van contingentie-ervaringen helpen om de intentionaliteit van het PPH te begrijpen. Ik kom tot de voorzichtige conclusie dat er een samenhang is tussen het levensverhaal van leraren en de intentionaliteit van het PPH bij een sterfgeval.

Ik sluit af met een opmerking over de rol van contingentie-ontmoeting. Het beeld dat uit de analyseresultaten naar voren komt, is dat leraren levensgebeurtenissen overwegend immanent duiden, namelijk contingentie-ontkenning of contingentie-erkenning. Ik vermoed dat dit ook de reden is dat leraren bij de begeleiding van hun leerlingen contingentie niet duiden als een ontmoeting met een andere werkelijkheid. Op grond hiervan zou het voor de hand liggen dat deze leraren de dood duiden als de absolute grens van het leven, maar dat is niet het geval. Ze spreken over een werkelijkheid voorbij de absolute grens van de dood en gebruiken daarvoor de metafoor van de hemel. Dat is kenmerkend voor het contingentiebewustzijn van mensen in de laatmoderne tijd. Mensen beseffen en ervaren dat hun beslissings- en handelingsruimte is gegroeid (Joas 2012). Bij de vorming van hun identiteit spelen tradities steeds minder een rol en zijn de sociale vormen die individuele keuzes beperken verzwakt of verdwenen. Ze scheppen hun eigen handelings- en interpretatiekader door een levensverhaal te construeren en het aan te passen aan de veranderende omstandigheden. Hun biografie is een keuzebiografie geworden.

\section{Afsluiting}

Er is nog maar weinig onderzoek gedaan naar de rol van religie in de professionele identiteit van leraren in het Nederlandse katholieke basisonderwijs. Om deze rol te achterhalen richtte ik me op levensdoelen en de zingeving aan autobiografische contingentie-ervaringen. Aanname daarbij is dat zingeving een interpretatief proces is dat voor religieuze en niet-religieuze leraren hetzelfde is. Het lijkt erop dat het een veelbelovende benadering is om onderzoek 
te doen naar 'persoonlijke religie' (James 1902) in een geïndividualiseerde, pluriforme samenleving. Verder is het belangrijk om het onderzoek naar het pedagogische handelen bij sterfgevallen niet te beperken tot het competent aanwenden van technische kennis. Het is niet alleen van belang om te weten hoe er gehandeld moet worden, maar ook om te weten welke beslissingen er genomen worden in onverwachte situaties en wat de rol daarbij is van praktijkkennis en van het eigen levensverhaal. Professionele kennis is dus niet alleen technisch, maar ook reflexief.

Op de tweede plaats sta ik stil bij de vraag wat dit onderzoek betekent voor het opleiden van leraren. Uit de casusbeschrijvingen komt naar voren dat praktische kennis nodig is om kinderen goed te begeleiden bij een sterfgeval. Deze kennis is nodig om in onverwachte, unieke situaties de juiste beslissingen te kunnen nemen. Van Veen en Janssen (2018) geven suggesties aan lerarenopleiders voor het werken met praktijkkennis. Een belangrijk onderdeel van deze suggesties is dat leraren het belang van praktijkkennis zelf ervaren. Een knelpunt bij het zelf laten ervaren van praktijkkennis bij sterfgevallen is dat deze zich vaak onverwacht aandienen en niet geschikt zijn als leersituatie voor studenten. In dat geval kan het werken met bestaande casestudies uitkomst bieden. Bij het opleiden voor zorgberoepen zoals arts, therapeut, verpleegkundige en geestelijk verzorger wordt er al langer gewerkt met casestudies (Menken-Bekius \& Schaap-Jonker 2010). Als studenten zelf weinig praktijkervaring hebben, worden bestaande casusbeschrijvingen gebruikt (Gärtner 2019). Bij de casusbeschrijvingen zouden de volgende vragen aanknopingspunten kunnen bieden voor wat studenten kunnen leren. Wat zijn mijn eigen ervaringen met het overlijden van dierbaren? Wat betekenen deze ervaringen met de dood voor mijn handelen bij een sterfgeval? Hoe vertel ik aan een kind dat een dierbare is overleden? Wat kan ik met een klas doen in de tijd tussen het overlijden van een dierbare en haar of zijn uitvaart? Wat is mijn rol tijdens de uitvaart? Wat doe ik met een klas in de periode na de uitvaart van de dierbare? Wat betekent dit voor de overdracht van de klas aan mijn collega? Bij het beantwoorden van deze vragen kunnen studenten ook theoretische kennis raadplegen en ervaren leraren interviewen. Op deze manier worden theoretische kennis en praktijkkennis met elkaar verbonden.

Ik sluit af met een suggestie voor vervolgonderzoek. Om te voorkomen dat er een eenzijdig beeld van praktijkkennis bij het omgaan met sterfgevallen ontstaat, is het van belang om casuïstiek te verzamelen op verschillende scholen en klassen en hiervan verhalen te maken voor het opleiden van leraren (Simons 2009). 


\section{Noot}

1 Bij het open coderen wordt zo dicht mogelijk bij het empirische materiaal gestart. Bij axiaal coderen wordt gezocht naar verbindingen tussen de open codes en wordt geprobeerd daarin thema's te ontdekken. Bij selectief coderen worden de fragmenten met dezelfde axiale codes onderling vergeleken. Ze helpen om een verbinding te leggen tussen empirie en theorie en geven relaties weer die kunnen helpen bij het beantwoorden van de centrale vraagstelling (Bleijenbergh 2016).

\section{Literatuur}

Abma, T.A., \& R.E. Stake (2014),

Science of the particular. An advocacy of naturalistic case study in health research, in: Qualitatieve Health Research, 24 (8), 1150-1161.

Alisic, E. (2011),

Children and trauma: a broad perspective on exposure and recovery (proefschrift), Utrecht: Universiteit van Utrecht.

Bernts, T. \& J. Berghuijs (2016),

God in Nederland 1966 - 2015, Utrecht: Ten Have.

Bleijenbergh, I. (2016),

Kwalitatief onderzoek in organisaties (tweede druk), Amsterdam: Boom.

Böhm, W. (2011),

Theorie und Praxis: Eine Einführung in das pädagogische Grundproblem (3e uitgebreide druk), Würzburg: Königshausen \& Neumann.

Böhm, W., E. Schiefelbein \& S. Seichter (2017),

Projekt Erziehung: ein Lehr- und Lernbuch (5e herziene druk), Paderborn: Ferdinand Schöningh.

Brand, J.A.M. van den (2016),

Levensverhaal en pedagogische handelingsoriëntatie in de laatmoderne tijd: een kwalitatieve survey onder leraren in het Nederlandse katholieke basisonderwijs, (proefschrift, Radboud Universiteit Nijmegen), Zürich: LIT Verlag.

Clandinin, D.J. (2016),

Engaging in narrative inquiry, New York: Routledge Taylor \& Francis Group.

Elbaz-Luwisch, F. (2005),

Teachers' voices: storytelling and possibility, Greenwich: Age Publishing

Friese, S. (2019),

Qualitative data analysis with Atlas.ti. (derde druk), London: Sage.

Gärtner, S. (2019),

Van onschatbare waarde. Case study in probleemgestuurd hoger onderwijs, in:

Handelingen, 46 (2), 7-17. 
Göhlich, M. \& J. Zirfas (2007),

Lernen. Ein pädagogischer Grundbegrif, Stuttgart: Kohlhammer.

James, W. (1902),

The Varieties of Religious Experience, London: Longmans Green.

Joas, H. (2004),

Braucht der Mensch Religion: Über Erfahrungen der Selbsttranszendenz, Freiburg: Herder.

Joas, H. (2012),

Glaube als Option. Zukunftsmöglichkeiten des Christentums, Freiburg: Herder.

Manen, M. van (2014),

Weten wat te doen wanneer je niet weet wat te doen. Pedagogische sensitiviteit in de omgang met kinderen, Driebergen: Nivoz.

Menken-Bekius, C. \& H. Jonker-Schaap (red.) (2010),

Ervaring leert, Kampen: Kok.

Ricken, N. (1999),

Kontingenz: Markierungen im Pädagogischen Diskurs, Würzburg: Königshausen \& Neumann.

Ricoeur, P. (2005),

Das Selbst als ein Anderer, München: Wilhelm Fink Verlag.

Riesebrodt, M. (2009),

The promise of salvation (a theory of religion), Chicago: The University Press.

Scherer-Rath, M. (2013),

Ervaring van contingentie en spirituele zorg, in: Psyche en Geloof, 24 (3), 184-195.

Simons, H. (2009),

Case study research in practice, London: Sage.

Smedes, T.A. (2016),

God, Iets of Niets? De postseculiere maatschappij tussen 'geloof' en 'ongeloof', Amsterdam:

Amsterdam University Press.

Spuij, M. (2014),

Prolonged grief in children and adolescents: Assessment, correlates, and treatment (proefschrift, Universiteit van Utrecht), Utrecht: Spuij.

Spuij, M. (2017),

Rouw bij kinderen en jongeren: over begeleiding van verliesverwerking, Amsterdam: Uitgeverij Nieuwezijds.

Straub, J. (2019a),

Das Erzählte Selbst. Kontouren einer interdisciplinären Theorie narrativer Identität. Ausgewählte Schriften, (Band 1 Historische und aktuelle Sondierungen autobiografische Selbstartikulation), Giessen: Psychosozial-Verlag. 
Straub, J. (2019b),

Das Erzählte Selbst. Kontouren einer interdisciplinären Theorie narrativer Identität. Ausgewählte Schriften, (Band 2 Begriffsanalysen und pragma-semantische Verortungen der Identität. Historische und aktuelle Sondierungen autobiografische Selbstartikulation), Giessen: Psychosozial-Verlag.

Straub, J. (2019C),

Das Erzählte Selbst. Kontouren einer interdisciplinären Theorie narrativer Identität. Ausgewählte Schriften, (Band 3 Zeitdiagnostische Klärungen und Korrekturen postmoderner Kritik), Giessen: Psychosozial-Verlag.

Veen, van K. \& F. Janssen (2018),

Praktijkkennis van leraren, in: Beijaard, D. (red.), Weten wat werkt. Onderwijsonderzoek vertaald voor lerarenopleiders, (tweede druk), Meppel: Ten Brink, 27-35.

Verschuren, P. \& H. Doorewaard (2015),

Het ontwerpen van een onderzoek, (vijfde druk), Amsterdam: Boom Lemma.

VKLO. (2014),

Kennisbasis godsdienst/levensbeschouwing rk., Eindhoven: VKLO. Geraadpleegd op 27 oktober 2018, van https://www.vklo.nl/images/documenten/publicatie_kennis bank_vklo.pdf

Wuchterl, K. (2011),

Kontingenz oder das Andere der Vernunft. Zum Verhältnis von Philosophie, Naturwissenschaft und Religion, Stuttgart: Steiner Verlag.

IJseling, H. (2020).

Bezield en bezielend onderwijs. Pedagogiek van onderbreking en verbinding, Rotterdam: Thomas More Hogeschool.

Zirfas, J. (2010),

Kontingenz und Tragik, in: Liebau, E. \& J. Zirfas (Hg.), Dramen der Moderne. Kontingenz und Tragik im Zeitalter der Freiheit, 9-30, Bielefeld: Transcript. 


\section{Bijlage:}

Tabel 1: Gefingeerde naam, leeftijd en religieuze zelfdefinitie van de respondent $(\mathrm{N}=7)$

\begin{tabular}{l|l|l} 
Naam & \multicolumn{1}{l}{ Leeftijd } & neligieuze zelfdefinitie \\
\hline Aarts & 40 jaar & christelijk \\
\hline Bos & 31 jaar & niet-christelijk \\
\hline Cox & 58 jaar & niet-christelijk \\
\hline Derks & 25 jaar & christelijk \\
\hline Evers & 38 jaar & niet-christelijk \\
\hline Faber & 30 jaar & christelijk \\
\hline Geurts & 65 jaar & \\
\hline
\end{tabular}

